\title{
Heavy Metal Levels in Some Popular Vegetables from Some Selected Markets in Saudi Arabia
}

\author{
Olfat M. Nassar ${ }^{(1,2)}$, Heba A. Nasr ${ }^{(3)}$, Mohamed H. El-Sayed ${ }^{(3)}$ and Abd El-Nasser \\ A. Kobisi(4)\# \\ ${ }^{(1)}$ Department of Home Economics (Nutrition), Faculty of Science and Arts, Northern \\ Border University, Kingdom of Saudi Arabia; ${ }^{(2)}$ Nutrition and Food Sciences \\ Department, Faculty of Home Economics, Minufiya University, P.O Box. 14442 \\ Minufya, Shibin El Kom, Egypt; (3)Department of Biology, Faculty of Science and \\ Arts, Northern Border University, Kingdom of Saudi Arabia; (4)Plant Protection \\ Department, Desert Research Center, El-Mataria, Cairo, Egypt.
}

$\mathbf{H}^{2}$ EAVY metals accumulation in vegetables is considered a world problem that may affect food safety and human health. In the present study, fifteen vegetable species consisting of five leafy; Arugula (Eruca sativa), Cabbage (Brassica oleracea), Corchorus (Corchorus capsularis), Dill (Anethum graveolens) and Parsley (Petroselinum sativum); five fruits; Cucumber (Cucumis sativus), Eggplant (Solanum melongena), Green pepper (Capsicum annuum), Tomato (Solanum lycopersicum) and Zucchini (Cucurbita pepo); in addition to five tubers; Garlic (Allium sativum), Onion (Allium cepa), Radish (Raphanus sativus), Potato (Solanum tuberosum) and Yam (Ipomoea batatas) were purchased from the local markets in Rafha Governorate at the Northern Border region in Kingdom of Saudi Arabia and tested for levels of cadmium $(\mathrm{Cd})$, lead $(\mathrm{Pb})$, arsenic $(\mathrm{As})$, iron $(\mathrm{Fe})$, copper $(\mathrm{Cu})$ and zinc $(\mathrm{Zn})$ metals using atomic absorption spectrometry. The results obtained showed that levels of $\mathrm{Cd}, \mathrm{Pb}, \mathrm{As}, \mathrm{Fe}, \mathrm{Cu}$ and $\mathrm{Zn}$ ranged from $0.13 \pm 0.073$ to $1.63 \pm 0.96 ; 0.33 \pm 0.18$ to $5.38 \pm 2.67$; $0.020 \pm 0.001$ to $0.052 \pm 0.033 ; 0.41 \pm 0.09$ to $10.81 \pm 7.29 ; 0.49 \pm 0.13$ to $4.37 \pm 0.89$ and $2.05 \pm 0.80$ to $94.20 \pm 73.28 \mu \mathrm{g} / \mathrm{g}$, respectively, for all vegetable samples. The highest average concentrations of $\mathrm{Cd}, \mathrm{Pb}, \mathrm{As}, \mathrm{Fe}, \mathrm{Cu}$ and $\mathrm{Zn}$ were recorded in leafy species as $0.46 \pm 0.19$ to $1.63 \pm 0.96 ; 0.00$ to $5.38 \pm 2.67 ; 0.00$ to $0.049 \pm 0.031 ; 2.95 \pm 1.47$ to $10.81 \pm 1.29 ; 1.42 \pm 0.73$ to $4.37 \pm 0.89 ; 4.63 \pm 1.37$ to $21.99 \pm 18.60 \mu \mathrm{g} / \mathrm{g}$, respectively. The highest mean levels $94.20 \pm 73.28$ and $10.81 \pm 7.29 \mu \mathrm{g} / \mathrm{g}$ were recorded for $\mathrm{Zn}$ and $\mathrm{Fe}$ in potato and corchorus, respectively; while the lowest mean levels $0.13 \pm 0.073$ and $0.33 \pm 0.18 \mu \mathrm{g} / \mathrm{g}$ were recorded for $\mathrm{Cd}$ and $\mathrm{Pb}$ in garlic and radish, respectively. The concentration of elements in these vegetables were within safety baseline levels for human consumption.

Keywords: Heavy metals, Vegetables, Rafha Governorate, Safe limit, Atomic absorption spectrometry.

\section{Introduction}

Most of the food materials are mainly derived from plants (vegetables, cereals, grains, fruits, etc.) and animals (Izah et al., 2016). Consumption of vegetables on a regular basis is one of the possible health-improving practice thus, vegetables are considered essential component in the human diet. Recently, people all over the world intake the fresh vegetables instead of red meat to reduce the incidence of chronic diseases such as diabetics, cancer, cardiovascular diseases and other agerelated diseases (Prakash et al., 2012).
Vegetables act as essential diet because their contributing of vitamins, proteins, carbohydrates, calcium, iron and other short supply nutrients (Amin et al., 2013; Siegel et al., 2014 and Latif et al., 2018). Consumption of vegetables provide the body of the living organisms with trace elements and heavy metals which are essential for the good health (Mohamed et al., 2003).

Vegetables provide the well-known trace elements and heavy metals. Minor or trace elements are essential for good health if they come from an organic or plant source. In contrast, if they come from an inorganic or metallic source,

\#Corresponding author email: nasrkobisi77@yahoo.com

DOI: $10.21608 /$ ejbo.2018.4548.1192

Edited by: Prof. Dr. Wedad Kasim, Faculty of Science, Tanta University, Tanta, Egypt.

C2018 National Information and Documentation Center (NIDOC) 
they become toxic. The processes of plant growth depend on the cycle of nutrients including trace elements, from soil to plant (Mohamed et al., 2003).

Contamination of food with heavy metals may be considered the most serious problem to our world (Zaidi et al., 2005). This problem can endanger the safety of plant products as feeds and foods in addition to its reduction of the plant productivity (Zheljazkov et al., 2006). Heavy metals are not biodegradable components with long biological half-lives and potential undesirable side effects when accumulated in different body organs (Sathawara et al., 2004 and Radwan \& Salama, 2006).

There are several factors for contamination with the heavy metal which including addition of metal-based pesticides and fertilizers, irrigation with contaminated water, industrial emissions and harvesting process (Duran et al., 2007 and Tuzen \& Soylak, 2007). Metals of different sources can pollute the soil then mix with soil solution after that they enter into the body of plants and accumulate in the edible parts either in high or in low concentrations (Zhou et al., 2016).

The levels of heavy metals in plants may depend on some factors such as cultivar, plant species, organ of the plant, growth stage, bioavailability of heavy metals in the soil and environmental conditions (Intawongse \& Dean, 2006 and Naser et al., 2011). Although vegetables are considered one of the most important dietary source of essential nutrients, it may contain high concentrations of heavy metals (Wiesler, 2012).

Heavy metals may accumulate in plant roots such as $\mathrm{Pb}, \mathrm{Cr}$ and $\mathrm{As}$ or translocate to the shoot system such as $\mathrm{Zn}, \mathrm{Cd}$ and Fe. Their concentrations are higher in roots, stems, followed by leaves and fruits (Vamerali et al., 2010). For utilization by living organisms, heavy metals can be utilized in small quantities and known as essential metals such as $\mathrm{Cr}, \mathrm{Cu}, \mathrm{Mn}, \mathrm{Ni}, \mathrm{Zn}$ or toxic and known as non-essential such as As, $\mathrm{Pb}, \mathrm{Cd}, \mathrm{Hg}$ (Vasić-Rački et al., 2010).

The essential micronutrients in higher plants, include $\mathrm{B}, \mathrm{Cl}, \mathrm{Cu}, \mathrm{Fe}, \mathrm{Mo}, \mathrm{Mn}, \mathrm{Ni}$ and $\mathrm{Zn}$ and non-essential such as $\mathrm{Hg}, \mathrm{Pb}, \mathrm{Cd}$ and $\mathrm{As}$ (Kirkby, 2012). The essential heavy metals are involved in many important processes in plant metabolism that include respiration, photosynthesis, synthesis of proteins, metalloproteins, functions of metalloenzymes, redox processes, plant defense mechanisms and regulation of genes (Broadley et al., 2012).

Nowadays, there is a great demand for food safety hence, the attention of many researchers to estimate the risks associated with consumption of many contaminated foodstuffs; heavy metals, pesticides and/or toxins in vegetables has increased (D'Mello, 2003; Latif et al., 2009 and Ismail \& Rashid, 2017). Globally, many people consume street foods every day as a part of their diet. Street food is recognized to pose significant public health risks. Because of persistent of heavy metals in nature, their accumulation in foods especially in vegetables and their potential toxicity, there is a great need to analyze and investigate their levels in the most common foodstuffs. This study therefore, focus on estimation of levels of six metals; cadmium $(\mathrm{Cd})$, lead $(\mathrm{Pb})$, arsenic (As), iron $(\mathrm{Fe})$, copper $(\mathrm{Cu})$ and zinc $(\mathrm{Zn})$ in fifteen vegetable species (five leafy; five fruits and five tubers) which were purchased from some local markets in Rafha Governorate at the Northern Border region in Kingdom of Saudi Arabia.

\section{Materials and Methods}

\section{Collection of samples}

In the present study, fifteen vegetable species consisting of five leafy (arugula, cabbage, corchorus, dill and parsley); five fruits (cucumber, eggplant, green pepper, tomato and zucchini) and five tubers (garlic, onion, radish, potato and yam) vegetable samples were purchased (3 samples of each species) from local retailers in Rafha Governorate at Northern Border region in Kingdom of Saudi Arabia (during the period of December-2017 to February-2018). Local and botanical names of these vegetable samples are given in Table 1. Parts of the samples that were obviously dust contaminated, damaged by insects or mechanically injured were removed. Then, the selected samples were washed in distilled water. Only edible parts of the samples were blended using a kitchen blender (Clikon) and stored in polyethylene bags at $-18^{\circ} \mathrm{C}$ until analysis.

\section{Reagents}

All reagents used were of analytical grade. All the plastic and glassware were cleaned by soaking them in a $10 \%$ nitric acid solution and rinsing 
them with distilled water prior to use. The element stock solutions $(1,000 \mathrm{mg} / \mathrm{L})$ and $\mathrm{HNO}_{3}$ used for digestion were provided by Merck (Darmstadt, Germany).

\section{Sample preparation}

Wet digestion method was used for sample preparation (Hseu, 2004). Ten grams of samples were weighed into digestion tubes and $10 \mathrm{ml}$ of concentrated $\mathrm{HNO}_{3}$ were added. The samples were digested for $45 \mathrm{~min}$ at $90^{\circ} \mathrm{C}$ and for $3 \mathrm{~h}$ at $130^{\circ} \mathrm{C}$, respectively. After digestion, the residue was filtered through blue band filter paper, then, the samples were diluted to $50 \mathrm{ml}$ with distilled water. Duplicated analysis was performed on the samples. Blank digestion was also carried out.

\section{Standard solutions}

The standard solutions were prepared by diluting the stock solutions of $1,000 \mathrm{mg} / \mathrm{L}$ of cadmium, lead, arsenic, iron, copper and zinc.

Heavy metal analysis

An atomic absorption spectrophotometer (AAS, model 220) was used to determine levels of $\mathrm{Cd}, \mathrm{Pb}, \mathrm{As}, \mathrm{Fe}, \mathrm{Cu}$ and $\mathrm{Zn}$ in the digested solutions. Working standard solutions of each element were prepared from stock standard solutions, this was done to ensure accuracy and that the analytical values were within the range of certified value. The sample preparation and heavy metals analyses were carried out at the Central Unit for Analysis and Scientific Services, National Research Center (NRC), El Bohouth St., Dokki, Giza, Egypt.

Daily intake and potential risk assessment

The estimated daily intake (EDI) of heavy metals depends on the corresponding concentrations in food and the daily consumption of food. The highest concentrations of the studied heavy metals were used for the calculation of EDI, assuming that human would expose to those highest levels. The EDI was calculated as follows:

$$
\mathrm{EDI}=\mathrm{C} \times \mathrm{W}
$$

where: $\mathrm{C}=$ Concentration of certain heavy metal in contaminated vegetable and $\mathrm{W}=$ Average of the daily consumption of the studied vegetable.

TABLE 1. Vegetable samples, with their local and botanical names.

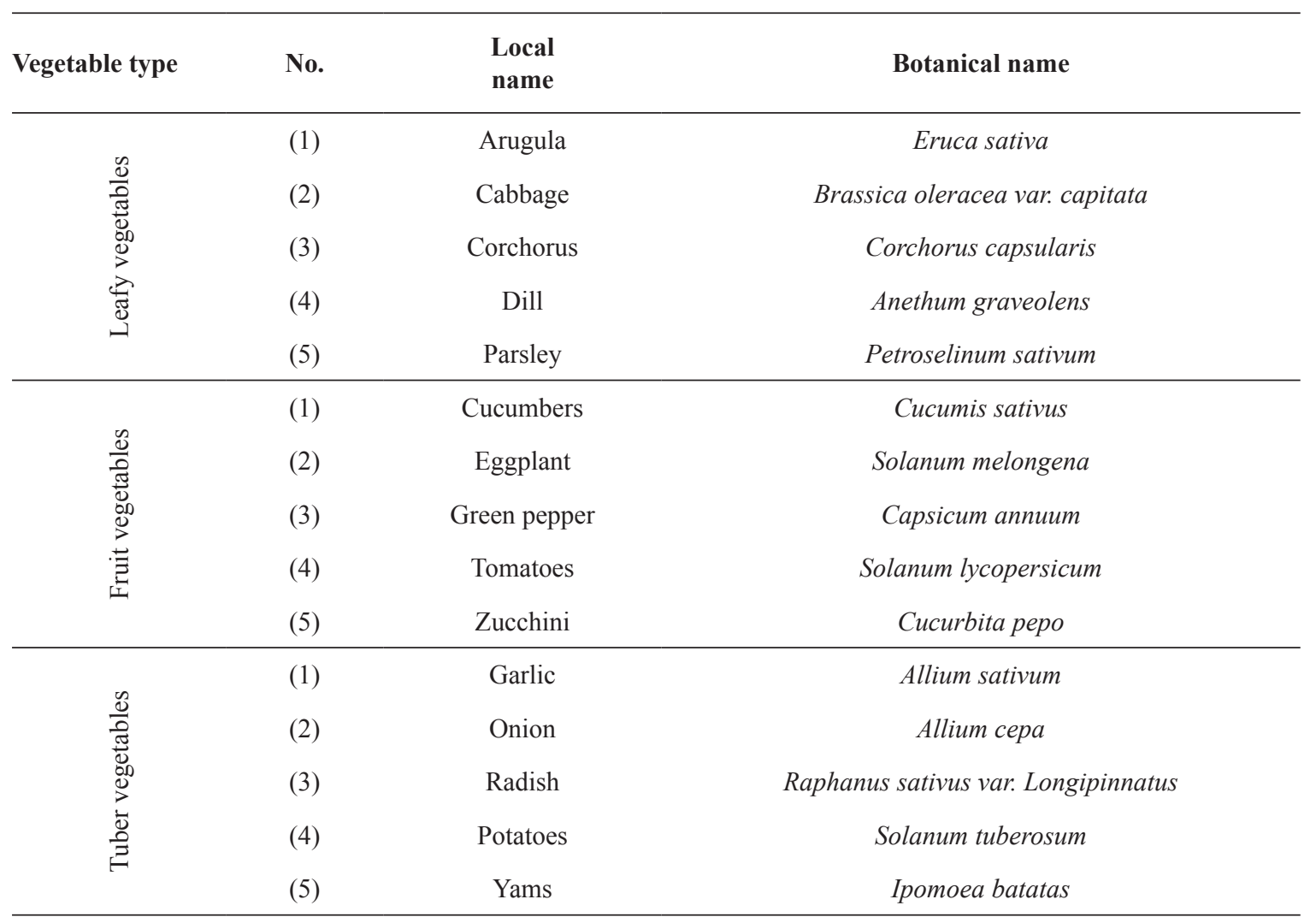


Also, the tolerable daily intake (TDI) of the heavy metals for an adult person of 70kg (assumed as an ideal body weight of an Saudi adult person) was calculated by multiply the value of TDI $(\mu \mathrm{g}$ $\mathrm{kg}^{-1}$ b.wt./day) (FAO/WHO, 2001 and Baars et al., 2001).

\section{Statistical analysis}

Three samples of each vegetable were assayed and analyzed individually. Data was reported as mean \pm SD. Two-Way ANOVA with replication was used to determine significant difference. Mean levels of metals were correlated with each other for the different vegetables (Neter \& Whitmore, 1993).

\section{$\underline{\text { Results and Discussion }}$}

Presence of heavy metals in vegetables may be coming from deposits of the environmental pollution or from contaminated soils, the metals are then pass through the roots to be deposit on the plant surface or accumulate in their edible parts (Haiyan \& Stuanes,
2003 and Nwajei, 2009). Vegetables are known as a good absorber of metals where it contains a wide range of concentrations of both essential and toxic metals (Lokeshwari \& Chandrappa, 2006 and Eslami et al., 2007).

Although a hug number of plants are investigated in the phytoremediation researches (Padmavathiamma \& Li, 2007 and Sarma, 2011), investigation of heavy metal levels in edible plants doesn't have attention with the degree that prevent reaching of the elevated concentrations of heavy metals to the consumer (Steenkamp et al., 2000 and Sharma et al., 2009).

\section{Maximum levels for heavy metals in vegetables}

Levels of six heavy metals in commonly consumed leafy, fruit and tuber vegetables for Rafha inhabitants are determined based on plants dry weight and recorded as mean $\pm \mathrm{SD}$ of three replicates (Tables 2 and 3).

TABLE 2. Mean concentration, standard deviation and range of $\mathrm{Cd}, \mathrm{Pb}$ and As metals in different vegetable samples $(\mu \mathrm{g} / \mathrm{g}$ dry wt) $(\mathrm{n}=3)$.

\begin{tabular}{|c|c|c|c|c|c|c|c|c|}
\hline \multirow{2}{*}{$\begin{array}{l}\text { Vegetable } \\
\text { type }\end{array}$} & \multirow{2}{*}{ No. } & \multirow{2}{*}{ Name } & \multicolumn{2}{|c|}{ Cadmium (Cd) } & \multicolumn{2}{|c|}{ Lead $(\mathrm{Pb})$} & \multicolumn{2}{|c|}{ Arsenic (As) } \\
\hline & & & Ranges & Mean \pm SD & Ranges & Mean \pm SD & Ranges & Mean \pm SD \\
\hline \multirow{6}{*}{ 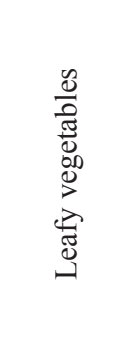 } & (1) & Arugula & nd & nd & nd & nd & nd & nd \\
\hline & (2) & Cabbage & $0.40-0.77$ & $0.46 \pm 0.19$ & $2.30-3.65$ & $2.34 \pm 0.90$ & $0.003-0.090$ & $0.031 \pm 0.035$ \\
\hline & (3) & Corchorus & $1.10-2.60$ & $1.41 \pm 0.75$ & $4.80-7.28$ & $4.88 \pm 1.66$ & $0.001-0.089$ & $0.049 \pm 0.031$ \\
\hline & (4) & Dill & $1.00-3.20$ & $1.63 \pm 0.96$ & $4.46-9.54$ & $5.38 \pm 2.67$ & nd & nd \\
\hline & (5) & Parsley & $1.00-2.03$ & $1.14 \pm 0.58$ & nd & nd & nd & nd \\
\hline & \multicolumn{2}{|c|}{ Mean values } & & 1.16 & & 4.2 & & 0.04 \\
\hline \multirow{6}{*}{ 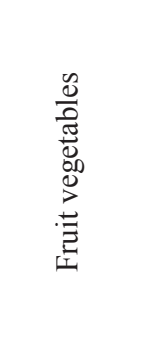 } & (1) & Cucumber & nd & nd & nd & nd & nd- 0.021 & $0.020 \pm 0.001$ \\
\hline & (2) & Eggplant & $0.30-0.59$ & $0.35 \pm 0.14$ & $4.10-7.10$ & $5.10 \pm 1.54$ & nd & nd \\
\hline & (3) & Green pepper & $0.25-0.43$ & $0.27 \pm 0.10$ & $4.30-8.08$ & $3.51 \pm 0.83$ & nd & nd \\
\hline & (4) & Tomato & $0.20-0.44$ & $0.25 \pm 0.11$ & $2.15-3.93$ & $2.40 \pm 0.99$ & nd & nd \\
\hline & (5) & Zucchini & nd & nd & nd & nd & nd & nd \\
\hline & \multicolumn{2}{|c|}{ Mean values } & & 0.29 & & 3.67 & & 0.020 \\
\hline \multirow{6}{*}{ 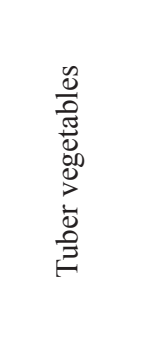 } & (1) & Garlic & $0.10-0.20$ & $0.13 \pm 0.073$ & $3.70-6.15$ & $3.93 \pm 1.49$ & nd & nd \\
\hline & (2) & Onion & nd & nd & nd & nd & $0.042-0.105$ & $0.052 \pm 0.033$ \\
\hline & (3) & Radish & $0.10-0.25$ & $0.14 \pm 0.063$ & $0.30-0.58$ & $0.34 \pm 0.15$ & nd & nd \\
\hline & (4) & Potato & $0.15-0.37$ & $0.21 \pm 0.096$ & $0.28-0.62$ & $0.38 \pm 0.18$ & nd & nd \\
\hline & (5) & Yams & $0.10-0.29$ & $0.19 \pm 0.067$ & nd & nd & $0.086-0.72$ & $0.30 \pm 0.252$ \\
\hline & \multicolumn{2}{|c|}{ Mean values } & & 0.16 & & 1.55 & & 0.17 \\
\hline
\end{tabular}

-nd: Not detected 
TABLE 3. Mean concentration, standard deviation and range of $\mathrm{Fe}, \mathrm{Cu}$ and $\mathrm{Zn}$ metals in different vegetable samples $(\mu \mathrm{g} / \mathrm{g}$ dry wt) $(\mathrm{n}=3)$.

\begin{tabular}{|c|c|c|c|c|c|c|c|c|}
\hline \multirow{2}{*}{$\begin{array}{l}\text { Vegetable } \\
\text { type }\end{array}$} & \multirow{2}{*}{ No. } & \multirow{2}{*}{ Name } & \multicolumn{2}{|c|}{ Iron $(\mathbf{F e})$} & \multicolumn{2}{|c|}{ Copper (Cu) } & \multicolumn{2}{|c|}{ Zinc (Zn) } \\
\hline & & & Ranges & Mean \pm SD & Ranges & Mean \pm SD & Ranges & $\operatorname{Mean} \pm$ SD \\
\hline \multirow{6}{*}{ 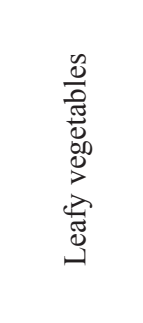 } & (1) & Arugula & $1.71-6.52$ & $2.95 \pm 1.47$ & $4.84-5.35$ & $4.37 \pm 0.89$ & $8.04-12.20$ & $9.91 \pm 1.49$ \\
\hline & (2) & Cabbage & $3.28-6.45$ & $4.31 \pm 1.00$ & $3.57-4.67$ & $3.47 \pm 0.88$ & $2.91-6.74$ & $4.63 \pm 1.37$ \\
\hline & (3) & Corchorus & $6.21-30.68$ & $10.81 \pm 1.29$ & $1.00-3.56$ & $2.1 \pm 0.90$ & $24.75-17.16$ & $21.13 \pm 2.69$ \\
\hline & (4) & Dill & $4.83-8.40$ & $6.53 \pm 1.32$ & $1.43-2.69$ & $1.65 \pm 0.67$ & $2.32-7.86$ & $5.09 \pm 2.57$ \\
\hline & (5) & Parsley & $3.13-9.14$ & $5.40 \pm 1.64$ & $1.12-2.56$ & $1.42 \pm 0.73$ & $2.43-41.55$ & $21.99 \pm 18.60$ \\
\hline & \multicolumn{2}{|c|}{ Mean values } & & 6.00 & & 2.60 & & 12.58 \\
\hline \multirow{6}{*}{ 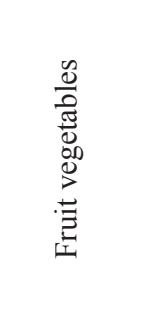 } & (1) & Cucumbers & $0.26-0.58$ & $0.41 \pm 0.09$ & 0.91-0.79 & $0.85 \pm 0.03$ & $0.65-3.46$ & $2.05 \pm 0.80$ \\
\hline & (2) & Eggplant & $1.86-3.63$ & $2.41 \pm 0.54$ & $0.54-0.53$ & $0.49 \pm 0.13$ & $2.33-5.48$ & $3.90 \pm 0.78$ \\
\hline & (3) & Green pepper & $0.81-1.30$ & $1.09 \pm 0.17$ & $0.92-1.93$ & $1.42 \pm 0.20$ & $2.52-9.63$ & $6.07 \pm 1.89$ \\
\hline & (4) & Tomatoes & $1.77-5.70$ & $3.65 \pm 1.38$ & $0.73-0.59$ & $0.66 \pm 0.16$ & $14.20-174.2$ & $50.48 \pm 19.00$ \\
\hline & (5) & Zucchini & $0.97-1.66$ & $1.35 \pm 0.27$ & $0.75-0.67$ & $0.71 \pm 0.07$ & $11.40-13.62$ & $12.51 \pm 1.46$ \\
\hline & \multicolumn{2}{|c|}{ Mean values } & & 1.78 & & 0.77 & & 15.0 \\
\hline \multirow{6}{*}{ 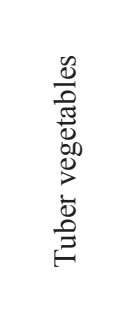 } & (1) & Garlic & $0.80-1.67$ & $0.97 \pm 0.44$ & $0.73-1.94$ & $1.33 \pm 0.49$ & $32.47-294.3$ & $81.69 \pm 73.68$ \\
\hline & (2) & Onion & $1.11-3.78$ & $1.78 \pm 1.24$ & $0.68-1.75$ & $1.21 \pm 0.15$ & $6.40-55.34$ & $61.74 \pm 29.54$ \\
\hline & (3) & Radish & $3.37-5.12$ & $3.71 \pm 0.89$ & $0.37-1.47$ & $0.92 \pm 0.22$ & 27.96-131.4 & $79.68 \pm 38.65$ \\
\hline & (4) & Potatoes & $4.11-6.56$ & $4.30 \pm 1.52$ & $0.75-0.93$ & $0.51 \pm 0.11$ & $21.84-79.13$ & $94.20 \pm 73.28$ \\
\hline & (5) & Yams & $2.12-8.82$ & $5.70 \pm 2.38$ & $1.75-5.93$ & $2.74 \pm 1.27$ & $33.88-131.4$ & $82.64 \pm 37.4$ \\
\hline & \multicolumn{2}{|c|}{ Mean values } & & 3.25 & & 1.34 & & 79.9 \\
\hline
\end{tabular}

The results obtained in this study showed that the levels of $\mathrm{Cd}, \mathrm{Pb}, \mathrm{As}, \mathrm{Fe}, \mathrm{Cu}$ and $\mathrm{Zn}$ ranged from $0.13 \pm 0.073$ to $1.63 \pm 0.96 ; 0.33 \pm 0.18$ to $5.38 \pm 2.67 ; \quad 0.020 \pm 0.001$ to $0.052 \pm 0.033$; $0.41 \pm 0.09$ to $10.81 \pm 7.29 ; 0.49 \pm 0.13$ to $4.37 \pm 0.89$ and $2.05 \pm 0.80$ to $94.20 \pm 73.28 \mu \mathrm{g} / \mathrm{g}$, respectively for all vegetable samples. These results were compared well with similar samples from other published works in different countries (Table 4).

It was noticed that, the highest average concentrations of $\mathrm{Cd}, \mathrm{Pb}, \mathrm{As}, \mathrm{Fe}, \mathrm{Cu}$ and $\mathrm{Zn}$ were recorded in leafy vegetables as $0.46 \pm 0.19$ to $1.63 \pm 0.96 ; 0.0$ to $5.38 \pm 2.67 ; 0.0$ to $0.049 \pm 0.031$; $2.95 \pm 1.47$ to $10.81 \pm 1.29 ; 1.42 \pm 0.73$ to $4.37 \pm 0.89$; $4.63 \pm 1.37$ to $21.99 \pm 18.60 \mu \mathrm{g} / \mathrm{g}$, respectively, compared with the lowest average concentration which detected in fruit vegetables as 0.0 to $0.35 \pm 0.14 ; 0.0$ to $5.10 \pm 1.54 ; 0.0$ to $0.020 \pm 0.001$; $0.41 \pm 0.09$ to $3.65 \pm 1.38 ; 0.49 \pm 0.13$ to $1.42 \pm 0.20$; $2.05 \pm 0.80$ to $50.48 \pm 19.00 \mu \mathrm{g} / \mathrm{g}$, respectively.

At the same time, the tuber vegetables were found to contain moderate average concentrations;
$0.13 \pm 0.073$ to $0.21 \pm 0.096 ; 0.0$ to $3.93 \pm 1.49 ; 0.0$ to $0.052 \pm 0.033 ; 0.97 \pm 0.44$ to $5.70 \pm 2.38 ; 0.51 \pm 0.11$ to $2.74 \pm 1.27 ; 61.74 \pm 29.54$ to $94.20 \pm 73.28 \mu \mathrm{g} / \mathrm{g}$ of $\mathrm{Cd}, \mathrm{Pb}, \mathrm{As}, \mathrm{Fe}, \mathrm{Cu}$ and $\mathrm{Zn}$, respectively. Vegetables absorb heavy metals from the soil and polluted air and water and especially leafy vegetables accumulate higher amounts of heavy metals in their leaves (Demirezen \& Aksoy, 2006; Sobukola et al., 2008 and Bagdatlioglu et al., 2010).

The results of the analysis showed that the levels of $\mathrm{Cd}$ in all samples were between $0.13 \pm 0.073 \mu \mathrm{g} / \mathrm{g}$ in garlic and $1.63 \pm 0.96 \mu \mathrm{g} / \mathrm{g}$ in dill plant with a range of $0.10-0.20$ and $1.00-3.20$, respectively. The highest levels of $\mathrm{Cd}$ in leafy vegetables were observed in cabbage, corchorus, dill and parsley. While the lowest levels of $\mathrm{Cd}$ in tuber vegetables were recorded in garlic, onion, radish, yam and potato in that order. Cadmium is a non-essential element in foods and natural waters and it accumulates in the human body, principally in the kidneys and liver. Various sources of environmental contamination have 
been implicated for its presence in foods (Divrikli et al., 2006).

Concerning the detected levels of $\mathrm{Pb}$, they were between $0.34 \pm 0.15 \mu \mathrm{g} / \mathrm{g}$ in radish and $5.38 \pm 2.67$ $\mu \mathrm{g} / \mathrm{g}$ in dill plant with a range of $0.30-0.58$ and 4.46-9.54, respectively. The highest levels of $\mathrm{Pb}$ were observed in leafy vegetables in corchorus and dill followed by fruit vegetables in eggplant and green pepper then in tuber vegetables in garlic. $\mathrm{Pb}$ being a serious cumulative body poison enters into the body system through air, water and food and cannot be removed by washing fruits and vegetables (Divrikli et al., 2003). The high levels of $\mathrm{Pb}$ in some of these plants may probably be attributed to pollutants in irrigation water, farm soil or due to pollution from the highway's traffic (Qui et al., 2000). While the lowest levels of $\mathrm{Pb}$ in tuber vegetables were recorded in radish and potato, also it was observed that $\mathrm{Pb}$ was not detected in some of the studied vegetable species as arugula, parsley, cucumber, zucchini, onion and yam.

Foods considered an important part of the arsenic intake, but because of the low level of arsenic in waters, soils, air, organisms and the other sources of nature, there is a few reports focused on estimation of arsenic level in vegetables especially for those grown in non-polluted soils (Chakraborti et al., 2002; Vela et al., 2004 and Shirkhanloo et al., 2015). In the present study As was not detected in 9 of the tested vegetables, but it was recorded in 6 species at very low concentration ranged between $0.020 \pm 0.001 \mu \mathrm{g} / \mathrm{g}$ in cucumber and $0.052 \pm 0.033 \mu \mathrm{g} / \mathrm{g}$ in onion with a range of $0.0-0.021$ and $0.042-0.105 \mu \mathrm{g} / \mathrm{g}$, respectively. To the best of our knowledge, in Saudi Arabia there are no studies concerned with estimation level of As in vegetables. Only one published work was focused on estimation of As level in some vegetable oils which ranged between 0.005-0.017 and 0.014-0.021 $\mu \mathrm{g} / \mathrm{g}$ (Ashraf, 2014).

The highest concentration of Fe was recorded in leafy vegetables in comparing with other vegetable types. Among leafy vegetables both corchorus and dill were the highest species $10.81 \pm 7.29$ and $6.53 \pm 1.32 \mu \mathrm{g} / \mathrm{g}$, respectively. The high accumulation of Fe in leafy vegetables than other vegetable types is due to that leaves are considered food making factories in plants. Our results were much lower than recorded by other published works in different regions in Saudi
Arabia (Mohamed et al., 2003; Al Jassir et al., 2005; Ali \& Al-Qahtani, 2012 and Ashraf, 2014).

In the present study, the concentration of $\mathrm{Cu}$ in all vegetable types ranged between $0.49 \pm 0.13 \mu \mathrm{g} / \mathrm{g}$ in eggplant and $4.37 \pm 0.89 \mu \mathrm{g} / \mathrm{g}$ in arugula with a range of 4.84-5.35 and 0.54-0.53, respectively. The highest levels of $\mathrm{Cu}$ were recorded in leafy vegetables; arugula, cabbage, corchorus, parsley and dill in that order, while the lowest levels of $\mathrm{Cu}$ were variable in both fruit and tuber vegetables. Because of $\mathrm{Cu}$ is necessary for the normal growth of plants, the vegetables contain amount of it in their tissues but the high level of $\mathrm{Cu}$ in vegetable may be due to using of copper-based fertilizers (FAO/WHO, 1988) in addition to leaves considered as entry points of heavy metals from the air (Demirezen \& Aksoy, 2006). The present study revealed that leafy vegetables accumulated $\mathrm{Cu}$ lower than the permissible level; $10.00 \mathrm{mg}$ $\mathrm{kg}^{-1}$, (FAO/WHO, 1999), and lower than another study in Saudi Arabia which were 33.22, 24.38, 14.07, 10.0, 9.07 and 6.76 $\mu \mathrm{g} / \mathrm{g}$ (Mohamed et al., 2003 and Ali \& Al-Qahtani, 2012).

Zinc is one of the most important metals for human growth and development (Divrikli et al., 2006). Its deficiency may be due to different reasons such as dietary inadequate intake or some zinc metabolic disorders as impaired absorption or excessive excretion or inherited defects in its metabolism (Colak et al., 2005 and Narin et al., 2005). In developing countries, the deficiency of $\mathrm{Zn}$ which attributed to consumption of plant foods having inhibitory components for $\mathrm{Zn}$ absorption is of growing interest (Divrikli et al., 2006). In this study, the recorded levels of $\mathrm{Zn}$ were varied between $2.05 \pm 0.80 \mu \mathrm{g} / \mathrm{g}$ in cucumber and $94.20 \pm 73.28 \mu \mathrm{g} / \mathrm{g}$ in potato with range of 0.65 3.46 and 21.84-79.13, respectively. The highest levels of $\mathrm{Zn}$ were recorded in tuber vegetables; potato, yam, garlic, radish and onion in that order at the same time the lowest levels were varied between leafy and fruit vegetables.

The maximum permissible levels of toxic metals in human foods are set by different national and international regulations; hence controlling the concentrations of heavy metals in foods is an increasingly important aspect of food quality (Radwan \& Salama, 2006 and Sobukola et al., 2010). Comparison of the obtained results with results of similar vegetable species published in different studies are recorded in Table 4. 
TABLE 4. Levels of heavy metals in the selected vegetables from Rafha markets, compared with earlier published results from other studies of the world.

\begin{tabular}{|c|c|c|c|c|c|c|c|}
\hline \multirow[b]{2}{*}{ No. } & \multirow{2}{*}{$\begin{array}{l}\text { Compared } \\
\text { studies }\end{array}$} & \multicolumn{6}{|c|}{ Levels of heavy metals in leafy vegetables $(\mu \mathrm{g} / \mathrm{g})$} \\
\hline & & $\begin{array}{l}\text { Cadmium } \\
\text { (Cd) }\end{array}$ & Lead $(\mathrm{Pb})$ & Arsenic (As) & Iron $(\mathrm{Fe})$ & Copper (Cu) & Zinc (Zn) \\
\hline \multicolumn{8}{|c|}{ Leafy vegetables } \\
\hline (1) & Present study & $0.46-1.14$ & nd-3.34 & $0-0.031$ & $2.95-4.31$ & $1.42-4.37$ & $4.63-21.99$ \\
\hline (2) & Saudi Arabia ${ }^{a}$ & $0.94-4.02$ & $2.19-5.31$ & NS & $119.5-495.9$ & $4.24-11.38$ & $21.54-35.54$ \\
\hline (3) & Saudi Arabia ${ }^{\mathrm{b}}$ & $0-1.22$ & $0-14.37$ & NS & $76.9-431$ & $0.43-3.34$ & $14.9-50.7$ \\
\hline (4) & Saudi Arabia ${ }^{\mathrm{c}}$ & $0.046-0.384$ & $0.059-0.101$ & NS & NS & $8.63-20.18$ & $19.24-41.93$ \\
\hline (5) & Turkey $^{\mathrm{d}}$ & nd -0.024 & $0.044-0.249$ & NS & $12.13-149.56$ & $0.70-6.60$ & $2.41-10.81$ \\
\hline (6) & Bangladesh $^{\mathrm{e}}$ & $0.002-0.35$ & $1.41-1.68$ & $0.37-0.48$ & NS & $4.15-6.28$ & $36.40-48.17$ \\
\hline \multicolumn{8}{|c|}{$\begin{array}{l}\text { Fruit vegetables } \\
\end{array}$} \\
\hline (1) & Present study & nd -0.25 & nd-2.40 & nd -0.020 & $0.41-1.09$ & $0.49-1.42$ & $2.05-50.48$ \\
\hline (2) & Saudi Arabia ${ }^{a}$ & $1.13-1.67$ & $3.32-3.67$ & NS & $112.8-196.1$ & $3.21-5.80$ & $22.44-29.78$ \\
\hline (3) & Saudi Arabia ${ }^{\mathrm{b}}$ & $0.59-0.8$ & $1.9-4.57$ & NS & $49-431$ & $2.48-4.49$ & $8.51-50.7$ \\
\hline (4) & Saudi Arabia ${ }^{c}$ & NS & NS & NS & NS & NS & NS \\
\hline (5) & Turkey $^{\mathrm{d}}$ & nd & $0.001-0.005$ & NS & $1.76-5.55$ & $0.51-0.85$ & $0.40-1.35$ \\
\hline (6) & Bangladesh $^{\mathrm{e}}$ & nd- -0.47 & $0.090-1.025$ & $0.15-0.54$ & NS & $5.78-26.18$ & $12.42-56.78$ \\
\hline \multicolumn{8}{|c|}{ Tuber vegetables } \\
\hline (1) & Present study & nd -0.13 & nd -0.33 & nd- -0.042 & $0.97-5.70$ & $0.51-2.74$ & $61.74-94.20$ \\
\hline (2) & Saudi Arabia ${ }^{a}$ & $0.93-0.99$ & $3.52-6.19$ & NS & $50.5-69.2$ & $3.29-6.08$ & $14.97-20.08$ \\
\hline (3) & Saudi Arabia ${ }^{b}$ & $0.76-0.84$ & $2.81-10.29$ & NS & $29.4-93.6$ & $0.88-2.81$ & $4.5-17.6$ \\
\hline (4) & Saudi Arabia ${ }^{c}$ & NS & NS & NS & NS & NS & NS \\
\hline (5) & Turkey $^{\mathrm{d}}$ & nd & $0.003-0.009$ & NS & 4.99-24.21 & $0.30-3.15$ & $2.57-2.95$ \\
\hline (6) & Bangladesh $^{\mathrm{e}}$ & $0.001-0.156$ & $0.22-0.350$ & $0.090-0.058$ & NS & $3.49-13.68$ & $21.15-32.19$ \\
\hline
\end{tabular}

$\begin{array}{rrrrr}\text { (6) } \quad \text { Bangladesh }^{\mathrm{e}} \quad 0.001-0.156 & 0.22-0.350 & 0.090-0.058 & \text { NS }\end{array}$

\begin{tabular}{llllllll}
\hline (7) & $\mathrm{FAO} / \mathrm{WHO}^{\mathrm{f}}$ & 0.2 & 0.3 & 0.1 & 425 & 73 & 99 \\
\hline
\end{tabular}

-nd: Not detected; ns: Not studied; ${ }^{\mathrm{A} A l i} \&$ Al-Qahtani (2012), ${ }^{\mathrm{b}}$ Mohamed et al. (2003), ${ }^{\mathrm{c}} \mathrm{Al}$ Jassir et al. (2005), ${ }^{\mathrm{d} B a g d a t l i o g l u}$ et al. (2010), ${ }^{\mathrm{e} A} \mathrm{Alam}$ et al. (2003) and fFAO/WHO (1999).

Form the above mentioned results it was clear that, there is no relationship between the highest heavy metal levels and period of storage of the plant part in the soil. It was known that the fruit vegetables have the longest storage period in cultivation comparing with the leafy and tuber vegetables. The obtained results ensured the mean values of the tested metals; $\mathrm{Cd}, \mathrm{Pb}, \mathrm{As}, \mathrm{Fe}, \mathrm{Cu}$ and $\mathrm{Zn}$ were $1.16,4.20,0.04,0.06,2.60,12.58 \mu \mathrm{g} / \mathrm{g}$ for leafy species; $0.29,3.67,0.20,1.78,0.77,15.0 \mu \mathrm{g} / \mathrm{g}$ for fruits and $0.16,1.55,0.17,3.25,1.34,79.9 \mu \mathrm{g} / \mathrm{g}$ for tuber species, respectively. Thus, we can conclude that the longest storage period was arranged as fruits $>$ tubers $>$ leafy vegetables while the highest mean values of each metal in the tested vegetables were arranged as leafy $>$ tubers $>$ fruits vegetables. Assimilation of elements is carried out in the root system of the plants thus, the direct contact between the soil and plant roots enable different metals to enter the tissues of the plant with nutrients and water (Smical et al., 2008). After the metals enter the plant body through the roots, they either sill present and stored in the roots or transported to other plant parts. Thus, plants accumulate the metals in edible or nonedible parts with concentrations enough to cause risks to human and animals that consumes these metals-containing plants (Arora et al., 2008).

In the present study, the obtained heavy metal concentrations are compared with the permissible limits of some international regulations (FAO/ WHO, 1999) and it was found that, the maximum levels, $0.042,5.70,4.37 \& 94.2 \mu \mathrm{g} / \mathrm{g}$ of As, Fe, Cu \& $\mathrm{Zn}$ are within $\mathrm{FAO} / \mathrm{WHO}$ safe limits; $0.1,425,73$ \& 
$99 \mu \mathrm{g} / \mathrm{g}$ for the same metals, respectively. While the obtained maximum levels of both $\mathrm{Cd}$ and $\mathrm{Pb} 1.14$ and $3.34 \mu \mathrm{g} / \mathrm{g}$ are higher than the safe limit of FAO/ WHO $0.2 \& 0.3 \mu \mathrm{g} / \mathrm{g}$, respectively with about 5 and 10 folds, especially in leafy and fruit vegetable species, but it was lower in the tuber vegetables.

Generally, the levels of heavy metals although they were higher than the permeable levels, they are lower than previously published works especially those in Saudi Arabia County, and those given by various authorities (FAO/WHO, 1988; 1999). At Rafha Governorate, most of the street consumable vegetables are locally cultured in Rafha farmers, where lower industrial activities and lower traffic in this region which result in the lowering of the contamination level.

Correlation coefficient of metals in the tested vegetables

The correlation between metal concentrations in the edible vegetables and their types was studied. In leafy vegetables, it was found a good positive correlation between the concentration of $\mathrm{Cd}$ and $\mathrm{Pb}$ $(\mathrm{r}=0.719), \mathrm{Cd}$ and $\mathrm{Fe}(\mathrm{r}=0.785), \mathrm{Pb}$ and $\mathrm{Fe}(\mathrm{r}=0.725)$, As and Fe $(r=0.670), \mathrm{Fe}$ and $\mathrm{Zn}(\mathrm{r}=0.521)$. But there is no significant correlation between $\mathrm{Cd}$ and As $(\mathrm{r}=0.146), \mathrm{Cd}$ and $\mathrm{Zn}(\mathrm{r}=0.305), \mathrm{Pb}$ and $\mathrm{As}(\mathrm{r}=$ $0.468)$, As and $\mathrm{Cu}(\mathrm{r}=0.019)$, As and $\mathrm{Zn}(\mathrm{r}=0.225)$. While it was noticed a negative correlation between the concentration of $\mathrm{Cd}$ and $\mathrm{Cu}(\mathrm{r}=-0.929), \mathrm{Fe}$ and $\mathrm{Cu}(\mathrm{r}=-0.596), \mathrm{Cu}$ and $\mathrm{Zn}(\mathrm{r}=-0.462), \mathrm{Pb}$ and $\mathrm{Cu}$ $(\mathrm{r}=-0.424)$.

In fruit vegetables, it was found positive correlation between $\mathrm{Cd}$ and $\mathrm{Pb}$ concentration $(\mathrm{r}=0.974), \mathrm{Cd}$ and $\mathrm{Fe}(\mathrm{r}=0.604), \mathrm{Fe}$ and $\mathrm{Cu}$ $(\mathrm{r}=0.506), \mathrm{Fe}$ and $\mathrm{Zn}(\mathrm{r}=0.822)$. But correlation is not significant between $\mathrm{Cd}$ and $\mathrm{Cu}(\mathrm{r}=0.005), \mathrm{Cd}$ and $\mathrm{Zn}(\mathrm{r}=0.194), \mathrm{Pb}$ and $\mathrm{Fe}(\mathrm{r}=0.465), \mathrm{Pb}$ and $\mathrm{Cu}(\mathrm{r}=-0.008), \mathrm{Pb}$ and $\mathrm{Zn}(\mathrm{r}=-0.015)$, As and $\mathrm{Cu}$ $(\mathrm{r}=0.037)$, As and $\mathrm{Zn}(\mathrm{r}=-0.358), \mathrm{Cu}$ and $\mathrm{Zn}(\mathrm{r}=-$ $0.259)$. While there was a negative correlation between the concentration of $\mathrm{Cd}$ and $\mathrm{As}(\mathrm{r}=-0.596)$, $\mathrm{Pb}$ and $\mathrm{As}(\mathrm{r}=-0.552)$, As and $\mathrm{Fe}(\mathrm{r}=-0.604)$.

Regarding the tuber vegetables, a positive correlation between $\mathrm{Cd}$ and $\mathrm{Fe}$ concentration $(\mathrm{r}=0.677), \mathrm{Cd}$ and $\mathrm{Zn}(\mathrm{r}=0.956), \mathrm{Pb}$ and $\mathrm{Fe}$ $(\mathrm{r}=0.655)$, As and $\mathrm{Fe}(\mathrm{r}=0.644)$, $\mathrm{As}$ and $\mathrm{Cu}$ $(\mathrm{r}=0.938)$. But, correlation was not significant between $\mathrm{Cd}$ and $\mathrm{Pb}(\mathrm{r}=0.027), \mathrm{Cd}$ and $\mathrm{As}(\mathrm{r}=0.229)$, $\mathrm{Cd}$ and $\mathrm{Cu}(\mathrm{r}=0.109), \mathrm{Pb}$ and $\mathrm{As}(\mathrm{r}=-0.372), \mathrm{Pb}$ and $\mathrm{Cu}(\mathrm{r}=0.089), \mathrm{Pb}$ and $\mathrm{Zn}(\mathrm{r}=-0.152)$, As and $\mathrm{Zn}(\mathrm{r}=-$
0.025), $\mathrm{Fe}$ and $\mathrm{Cu}(\mathrm{r}=0.399), \mathrm{Fe}$ and $\mathrm{Zn}(\mathrm{r}=0.494)$, $\mathrm{Cu}$ and $\mathrm{Zn}(\mathrm{r}=-0.142)$. The previously mentioned correlations indicated that the variations in the heavy metals (pollutants) were due to the same factors as soil, water or air pollutions as indicated by their positive correlations. Also, the variations in trace and essential elements depend on their content in the soil and their utilization by the plant organs and/or their partition in the plant. For $\mathrm{Cd}, \mathrm{Pb}, \mathrm{Cu}$ and $\mathrm{Zn}$ levels, a significant difference $(\mathrm{P}<0.05)$ at confidence level $95 \%$ was recorded between all vegetable samples. The solubility of heavy metals in the soil and their accumulation in the plants may be the cause for the detected differences in metals concentration for the tested vegetable species (Cordeiro et al., 2013).

\section{Assessment of potential risk (safe dose)}

In each survey study dealing with estimation of food contaminants the safety assessment is essential complementary section. To determine the estimated daily intake (EDI) for the studied 3 vegetables types, the obtained data of the levels of heavy metals were employed. We considered the daily consumption for the adult Saudi person (70kg weight) is 7.8 , 80.5 and $61 \mathrm{~g}$ of leafy, fruits and tuber vegetables, respectively. The data recorded in Table 5 showed that EDI of the metals under investigation were lower than those of tolerable daily intake (TDI) except in case of both $\mathrm{Cd}$ and $\mathrm{Pb}$. The results of this study in comparison with TDI values indicate that intakes of metals through leafy vegetables from Saudi Arabia would not mean a health hazards for consumers, but gets significance in light of the reported daily intakes for $\mathrm{Cd}$ and $\mathrm{Pb}$ through rice in Saudi diet as 67.41 $\mu \mathrm{g} \mathrm{Pb}$ and $10.3 \mu \mathrm{g} \mathrm{Cd}$ (Al-Saleh \& Shinwari, 2001).

Considering the Saudi nutritional habitats, an adult person $(70 \mathrm{~kg})$ consumes $7.8,80.5$ and $61 \mathrm{~g}$ of leafy, fruits and tuber vegetables, respectively in a daily manner. In this regards, calculated data in Table 5 revealed that values of the estimated daily intake (EDI) of the studied heavy metals, for $70 \mathrm{~kg}$ adult person, were markedly lower than those of tolerable daily intake (TDI) except in case of both $\mathrm{Cd}$ and $\mathrm{Pb}$. The results of this study in comparison with TDI values indicate that intakes of metals through leafy vegetables from Saudi Arabia would not mean a health hazards for consumers, but gets significance in light of the reported daily intakes for $\mathrm{Cd}$ and $\mathrm{Pb}$ through rice in Saudi diet as $67.41 \mu \mathrm{g} \mathrm{Pb}$ and 10.3 $\mu \mathrm{g}$ Cd (Al-Saleh \& Shinwari, 2001). 
TABLE 5. Estimated daily intake of heavy metals compared to the tolerable daily intake.

\begin{tabular}{|c|c|c|c|c|c|}
\hline \multirow[b]{2}{*}{ Heavy metals } & \multirow{2}{*}{$\begin{array}{c}\text { TDI* } \\
\left(\mu \mathrm{kg}^{-1} \text { b.wt/day }\right)\end{array}$} & \multirow{2}{*}{$\begin{array}{c}\text { TDI } * * \\
(70 \mu g \text { adult person/day) }\end{array}$} & \multicolumn{3}{|c|}{ EDI*** $(\mu \mathrm{g})$} \\
\hline & & & Leafy vegetables & Fruit vegetables & $\begin{array}{c}\text { Tuber } \\
\text { vegetables }\end{array}$ \\
\hline Cadmium & 0.2 & 14 & 8.89 & 91.77 & 69.54 \\
\hline Lead & 0.3 & 21 & 26.05 & 268.87 & 203.74 \\
\hline Arsenic & 0.1 & 7 & 0.327 & 3.38 & 2.56 \\
\hline Iron & 425 & 29750 & 44.46 & 458.8 & 347.7 \\
\hline Copper & 73 & 5110 & 34.08 & 351.78 & 266.57 \\
\hline Zinc & 99 & 6930 & 734.76 & 6580 & 5746 \\
\hline
\end{tabular}

"FAO/WHO, 1999. **TDI: Tolerable daily intake for assumed ideal Saudi body weight $(70 \mathrm{~kg})$, ***EDI: Estimated daily intake (calculated by multiply the highest detected value of certain metal with the daily consumed amount (g) of vegetable according to FAO/WHO (2003).

\section{Conclusion}

In the current study, we can conclude that, the tested heavy metals of the different species of vegetables were arranged as $\mathrm{Zn}>\mathrm{Fe}>\mathrm{Cu}>\mathrm{Pb}>\mathrm{Cd}>\mathrm{As}$. The leafy vegetables were found to contain the highest values of most heavy metals but within permissible levels. The heavy metal levels recorded in this study for leafy, fruit and tuber vegetables collected from Rafha Governorate at the Northern Border region in Kingdom of Saudi Arabia are within the standard permissible levels thus these vegetable species are suitable in the food composition for Rafha and Northern Border region inhabitants.

Acknowledgement: Olfat Mahmoud Nassar, Heba Ali Nasr, Mohamed Helal El-Sayed and Abd ElNasser Ahmed Kobisi gratefully acknowledge the approval and support of this research study by the grant No. 7313-SAR-2017-1-8-F from Deanship of Scientific Research, Northern Border University, Arar, KSA.

\section{References}

Al Jassir, M.S., Shaker, A. and Khaliq, M.A. (2005) Deposition of heavy metals on green leafy vegetables sold on roadsides of Riyadh City, Saudi Arabia. Bull. Environ. Cont. Toxicol. 75, 1020-1027.

Alam, M.M., Snow, E.T. and Tanaka, A. (2003) Arsenic and heavy metal contamination of vegetables grown in Samta village, Bangladesh. Sci. Total Environ. 308, 83-96.

Ali, M.H. and Al-Qahtani, K.M. (2012) Assessment of some heavy metals in vegetables, cereals and fruits in Saudi Arabian markets. Egypt J. Aquat. Res. 38, 31-37.
Al-Saleh, I. and Shinwari, N. (2001) Report on the levels of cadmium, lead and mercury in imported rice grain samples. Biol. Trace Element. Res. 83, 91-96.

Amin, N.U., Hussain, A., Alamzeb, S. and Begum, S. (2013) Accumulation of heavy metals in edible parts of vegetables irrigated with wastewater and their daily intake to adults and children, District Mardan, Pakistan. Food Chem. 136, 1515-1523.

Arora, M., Kiran, B., Rani, S., Rani, A. and Kaur, B. et al. (2008) Heavy metal accumulation in vegetables irrigated with water from different sources. Food Chem. 111, 811-815.

Ashraf, M.W. (2014) Levels of selected heavy metals in varieties of vegetable oils consumed in kingdom of saudi arabia and health risk assessment of local population. J. Chem. Soc. Pakistan, 36, 691-698.

Bagdatlioglu, N., Nergiz, C. and Ergonu, P.G. (2010) Heavy metal levels in leafy vegetables and some selected fruits. J. Food Protect. Safety, 5, 421-428.

Baars, A.J., Theelen, R.M.C., Janseen, P.J.C.M., Hesse, J.M. and van Apeldoorn, M.E. et al. (2001) ReEvaluation of human-toxicological maximum permissible risk levels. RIVM Rapport 711701025 , March 2001. http://www.rivm.nl/bibliotheek/ rapporten/711701025.pdf

Broadley, M., Brown, P., Cakmak, I., Rengel, Z. and Zhao, F. (2012) Function of nutrients: Micronutrients. In: "Mineral Nutrition of Higher Plants", Marschner, P. (Ed.), pp. 191-248. $3^{\text {rd }}$ ed. London, Academic Press.

Chakraborti, D., Rahman, M., Paul, K., Chowdhury, U., Sengupta, M., Lodh, D., Chanda, C., Saha, K. and Mukherjee, S. (2002) Arsenic calamity in the Indian subcontinent. Talanta, 58, 3-22. 
Colak, H., Soylak, M. and Turkoglu, O. (2005) Determination of trace metal content of herbal and fruit teas produced and marketed from Turkey. Trace Elem. Electroly. 22, 192-195.

Cordeiro, F., Baer, I., Robouch, P., Emteborg, H. and Can, S.Z. et al. (2013) Setting maximum limits for trace elements in baby food in European legislation: The outcome of International Measurement Evaluation Programme ${ }^{\circledR}-33$. Food Addit Contam Part A Chem Anal Control Expo Risk Assess 30, 678-686.

Demirezen, D. and Aksoy, A. (2006) Heavy metal levels in vegetables in Turkey are within safe limits for $\mathrm{Cu}$, $\mathrm{Zn}, \mathrm{Ni}$ and exceeded for $\mathrm{Cd}$ and $\mathrm{Pb}$. Journal of Food Quality, 29, 252-265.

Divrikli, U., Horzum, N., Soylak, M. and Elci, L. (2006) Trace heavy metal contents of some spices and herbal plants from western Anatolia, Turkey. J Food Sci. Tech. 41, 712-716.

Divrikli, U., Saracoglu, S., Soylak, M. and Elci, L. (2003) Determination of trace heavy metal contents of green vegetables samples from Kayseri- Turkey by flame atomic absorption spectrometry. Fresen Environ. Bull. 12, 1123-1125.

D’Mello, J.P. (2003) "Food safety: Contaminants and Toxins", pp. 191-215. Cambridge, CABI Publishing.

Duran, A., Tuzen, M. and Soylak, M. (2007) Trace element levels in some dried fruit samples from Turkey. Int. J. Food Sci. Nutr. 59, 581-589.

Eslami, A., Khaniki, R.J., Nurani, M., Meharasbi, M., Peyda, M. and Azimi, R. (2007) Heavy metals in edible green vegetables grown along the sites of the Zanjan roads Iran. J. Biol. Sci. 7, 943-948.

FAO/WHO (1988) Codex committee on food additives and contaminants, thirty-first session, The Hague, The Netherlands, 22-26 March 1999. Joint FAO/ WHO Food Standard Programme, Geneva, Switzerland.

FAO/WHO (1999). Joint FAO/WHO Expert committee on food cdditives. Summary and conclusions, In: $53^{\text {rd }}$ meeting, Rome, 1-10 June.

FAO/WHO (2001) Codex alimentarius twenty-fourth session, Geneva, Switzerland, 2-7 July 2001. ALINORM 01/12, Joint FAO/WHO Food Standards Programme, Geneva, Switzerland.
FAO/WHO (2003) GEMS/Food regional dites: Regional per capita consumption of raw and semi-processed agricultural commodities. Food Safety Department/ World Health Organization, Geneva, Switzerland, September 2003.

Haiyan, W. and Stuanes, A. (2003) Heavy metal pollution in air-water-soil-plant system of Zhuzhou city, Hunan province, China. Water Air Soil Pollut. 147, 79-107.

Hseu, Z.Y. (2004) Evaluating heavy metal contents in nine composts using four digestion methods. Bioresour. Technol. 95, 53-59.

Intawongse, M. and Dean, J.R. (2006) Uptake of heavy metals by vegetable plants grown on contaminated soil and their bioavailability in the human gastrointestinal tract. Food Addit. Contam. 23, 36-48.

Ismail, A.S. and Rashid, M.S. (2017) Health risk assessment of heavy metals for population via consumption of vegetables collected from Khassa River, Kirkuk City, Northern Iraq. Int. J. Curr. Res. Acad. Rev. 5, 104-110.

Izah, S.C., Kigigha, L.T. and Anene, E.K. (2016) Bacteriological quality assessment of malus domestica borkh and Cucumis sativus L. in Yenagoa Metropolis, Bayelsa state, Nigeria. Brit. J. Appl. Res. 1, 5-7.

Kirkby, E (2012) Introduction, definition and classification of nutrients. In: " Mineral Nutrition of Higher Plants", Marschner, P. (Ed.), p. 3-5, $3^{\text {rd }}$ ed. London, Academic Press.

Latif, A.G., Ardalan, A.M., Mohammadi, M.T., Hosseini, H.M. and Karimian, N. (2009) Solubility test in some phosphate rocks and their potential for direct application in soil. W. Appl. Sci. J. 6, 182-190.

Latif, A., Bilal, M., Asghar, W., Azeem, M. and Ahmad, M.I. et al. (2018) Heavy metal accumulation in vegetables and assessment of their potential health risk. J. Environ. Analy. Chem. 5, 234.

Lokeshwari, H. and Chandrappa, G.T. (2006) Impact of heavy metal contamination of Bellandur Lake on soil and cultivated vegetation. Curr. Sci. 91, 622627.

Mohamed, A.E., Rashed, M.N. and Mofty, A. (2003) 
Assessment of essential and toxic elements in some kinds of vegetables. Ecotoxicol. Environ. Saf. 55, 251-260.

Narin, I., Tuzen, M., Sari, H. and Soylak, M. (2005) Heavy metal content of potato and corn chips from Turkey. Bull. Environ. Contam. Toxicol. 74, 10721077.

Naser, H.M., Sultana, S., Mahmud, N.U., Gomes, R. and Noor, S. (2011) Heavy metal levels in vegetables with growth stage and plant species variations. Bangl. J. Agricult. Res. 36, 563-74.

Neter, W., Whitmore (1993) "Applied Statistics", $4^{\text {th }}$ ed, Allyn and Bacon, Boston, MA.

Nwajei, G.E. (2009) Trace elements in soils and vegetations in the vicinity of shell petroleum development company operating area in Ughelli, delta state of Nigeria. Am. Euras. J. Sust. Agricult. 3, 574-578.

Padmavathiamma, P.K. and Li, L.Y. (2007) Phytoremediation technology: Hyper accumulation metals in plants. Water Air Soil Pollut. 184, 105-126.

Prakash, D., Upadhyay, G., Gupta, C., Pushpangadan, P. and Singh, K.K. (2012) Antioxidant and free radical scavenging activities of some promising wild edible fruits. Int. Food Res. J. 19, 1106-1116.

Qui, X.X., Huang, D.F., Cai, S.X., Chen, F., Ren, Z.G. and Cai, Y.C. (2000) Investigations on vegetables pollution and pollution sources and its control in Fuzhou, Fujian Province. Fuj. J. Agricult. Sci. 15, 16-21.

Radwan, M.A. and Salama, A.K. (2006) Market basket survey for some heavy metals in Egyptian fruits and vegetables. Food Chem. Toxic. 44, 1273-1278.

Sarma, H. (2011) Metal hyper accumulation in plants: A review focusing on phytoremediation technology. $J$. Environ. Sci. Tech. 4, 118-138.

Sathawara, N.G., Parikh, D.J. and Agarwal, Y.K. (2004) Essential heavy metals in environmental samples from Western India. Bull. Environ. Cont. Toxic. 73, 756-761.

Sharma, R.K., Agrawal, M. and Marshall. F.M. (2009) Heavy metals in vegetables collected from production and market sites of a tropical urban area of India. Food Chem. Toxic. 47, 583-591.

Shirkhanloo, H., Seyed, A., Hajiseyed, M., Nasrin, S., Seyyed, A., Moussavi, N. and Hadi, F. (2015) The evaluation and determination of heavy metals pollution in edible vegetables, water and soil in the south of Tehran province by GIS. Arch. Environ. Protec. 41, 64-74.

Siegel, K.R., Ali, M.K., Srinivasiah, A., Nugent, R.A. and Narayan, K.M. (2014) Do we produce enough fruits and vegetables to meet global health need? PloS One, 9, e104059.

Smical, A., Hotea, V., Oros, V., Juhasz, J. and Pop, E. (2008) Studies on transfer and bioaccumulation of heavy metals from soil into lettuce. Environ. Eng. Manag. 7, 609-615.

Sobukola, O.P., Awonorin, S.O., Idowu, M.A. and Bamiro, F.O. (2008) Chemical and physical hazard profile of 'robo' processing - a street vended melon snack. Int. J. Food Sci. Tech. 43, 237-242.

Sobukola, O.P., Adeniran, O.M., Odedairo, A.A. and Kajihausa, O.E. (2010) Heavy metal levels of some fruits and leafy vegetables from selected markets in Lagos, Nigeria. Afr. J. Food Sci. 4, 389-393.

Steenkamp, V., Von arb, M. and Stewart, M.J. (2000) Metal concentrations in plants and urine from patients treated with traditional remedies. Forensic Sci. Int. 114, 89-95.

Tuzen, M. and Soylak, M. (2007) Evaluation of trace element contents in canned foods marketed from Turkey. Food Chem. 102, 1089-1095.

Vamerali, T., Bandiera, M. and Mosca, G. (2010) Field crops for phytoremediation of metal-contaminated land. A review. Environ. Chem. Lett. 8, 1-17.

Vasić-Rački, Đ., Onečišćivači, I.O. and Industrijske, O.T. (2010) Pollutants from the environment. Industrial pollutants; in Croatian. In: "Chemical and physical hazards in food; in Croatian", Hengl, B., (Ed.), p. 50-65. Kemijske i fizikalne opasnosti u hrani. Osijek. Hrvatska agencija za hranu.

Vela, N., Heitkemper, D. and Stewart, K. (2004) Arsenic extraction and speciation in carrots using accelerated solvent extraction, liquid chromatography and plasma mass spectrometry. Analyst, 126, 1011-1017. 
Wiesler, F. (2012) Nutrition and quality. In: "Mineral Nutrition of Higher Plants", Marschner, P. (Ed.), pp. 271-82, $3^{\text {rd }}$ ed. London, Academic Press.

Zaidi, M.I., Asrar, A., Mansoor, A. and Farooqui, M.A. (2005) The heavy metal concentrations along roadside trees of Quetta and its effects on public health. J. Appl. Sci. 5, 708-711.

Zheljazkov, V.D., Craker, L.E. and Xing, B. (2006) Effects of $\mathrm{Cd}, \mathrm{Pb}$, and $\mathrm{Cu}$ on growth and essential oil contents in dill, peppermint and basil. Environ. Exper. Bot. 58, 9-16.

Zhou, H., Yang, W.T., Zhou, X., Liu, L. and Gu, J.F. et al. (2016) Accumulation of heavy metals in vegetable species planted in contaminated soils and the health risk assessment. Int. J. Environ. Res. Public Health, 13, 289.

(Received $23 / 7 / 2018$ accepted $23 / 11 / 2018$ )

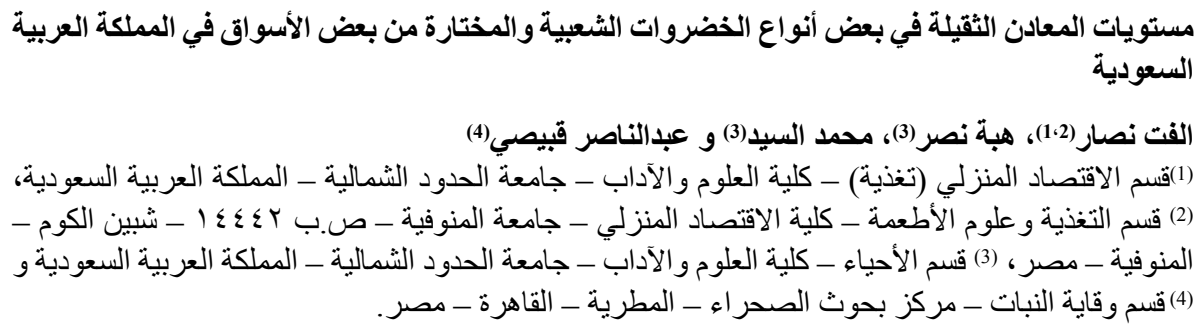

تر اكم المعادن الثقيلة في الخضرو ات يُعد مشكلة عالمية خطيرة على سلامة الغذاء وصحة الإنسان. في هذه الدر اسة فئ

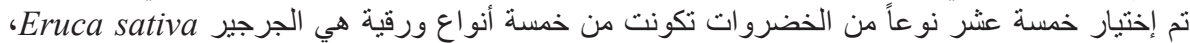

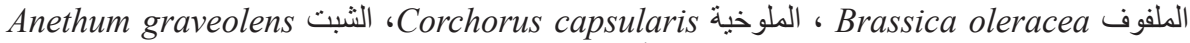
و البقدونس Petroselinum sativum؛ خمس أنواع فو اكه هي الخيار Cucumis sativus، الباذنجان

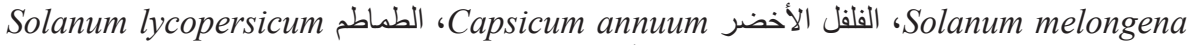
و الكوسة Cucurbita pepo بالإضافة إلى خمسة أنو اعدرنبة هي الثوم Allium sativum البصن (Cepa

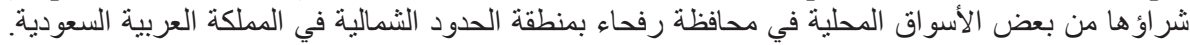

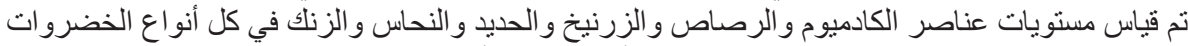

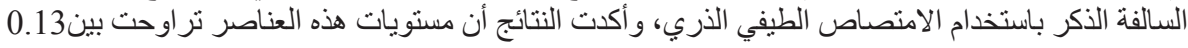

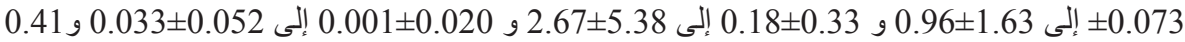

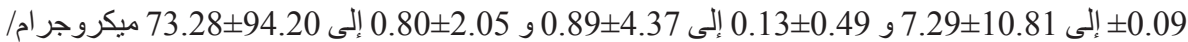

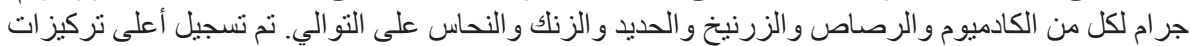

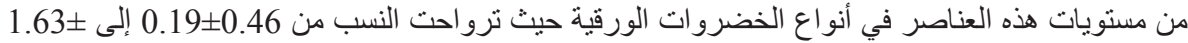

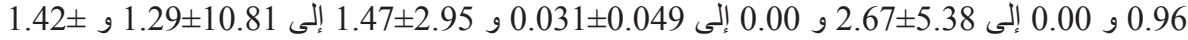

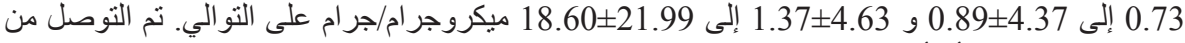

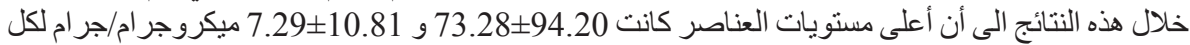
من الزنك و الحديد في البطاطا Solanum tuberosum و الملوخية بينما كانت أدنى المستويات

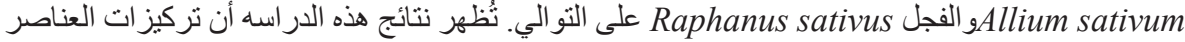
الثقبلة التي تم قياسها في أنو اع الخضرو ات محل الدر اسة ضمن المستو يات المسموح بها للاستهلاك البشري. 